\title{
The Examining of GSM Operators' Customer Complaint Management (CCM) Applications in Turkey with Discriminant Analysis
}

\author{
Yildiray Kizgin $^{1} \&$ Tahir Benli ${ }^{2}$ \\ ${ }^{1}$ Mugla Vocational College, Mugla Sitki Kocman University, Mugla, Turkey \\ ${ }^{2}$ Department of Business Administration, Kastamonu University, Kastamonu, Turkey \\ Correspondence: Yildiray Kizgin, Mugla Vocational College, Mugla Sitki Kocman University, 48000, Mugla, \\ Turkey. Tel: 90-252-211-3193. E-mail: ykizgin@mu.edu.tr
}

Received: December 7, 2012

Accepted: December 28, 2012 Online Published: January 15, 2013

doi:10.5539/ijbm.v8n3p1

URL: http://dx.doi.org/10.5539/ijbm.v8n3p1

\begin{abstract}
In the active decision-making process, during the purchase, the most notable case is satisfaction or dissatisfaction of the customer is caused in the purchasing decision. In the recent years, the new structures have been composed under the name of "Customer Complaint Management" (CCM). In terms of emphasizing the importance of research and in order to understand the effectiveness of CCM, researched that how the consumers were evaluated the CCM performance of GSM companies in Turkey. The research was conducted on the primarily-handed data. This study is a survey that aims to evaluate the "solving the consumer's complaint for the Turkcell, Vodafone, Avea companies". And their performances related to CCM dimensions such as transparency, accessibility, responsiveness, objectivity and consumer oriented strategies is perceived by the consumers. Frequency distribution of survey data investigated and reliability of research variables tested by Cronbach Alpha analysis. Two discrimination functions were evaluated. With the first discrimination function, it is seen that the Avea has the highest value in comparison with the other companies $(0,566)$; with the second discrimination function, it is seen that Vodafone has the highest value $(0,583)$. Turkcell has no highest discrimination value in comparison with the other GSM companies.
\end{abstract}

Keywords: Customer Complaint Management (CCM), GSM firms, discriminant analysis

\section{Introduction}

Whatever its identity within the sector is one of the most significant problems threatening the companies in today's market conditions is the risk of considerably reduction of the customer loyalty which was gradually acquired in years. Intensively preferred marketing strategies of today are the adaptation of the rapid technological developments to the productions in order to increase the customer loyalty, and differentiation and diversification of goods and services. However, what direct the consumers to purchase are not always the needs, but the perception of the stimulants of marketing and sales strategies surrounding him.

When the changes in marketing strategies are examined, it is noticed that consumers in the 90 s recognized that they had something to say and needed to make it accepted while the companies were trying to sell goods/services through mass marketing strategies in the 70s and 80s. Accordingly, the companies realized that they had to care about the consumers and understand them in order to exist in the market (Bozkurt, 2000), and they directed to target markets. The integrity in the markets in the 2000s was replaced by more personal service, well, and interest. Customers started to act as organized masses against the companies rather than act as single individuals.

While the goods and services the consumers prefer are sometimes the ones they previously used, those may sometimes be their preferences which they opt with new assessments and the influence of reference groups. During the active decision-making process, when the consumer is at the edge of making the decision purchase a good or a service, the most prominent state awaiting the consumer after purchasing is the satisfaction and dissatisfaction of his decision to purchase.

When considering the fact that to keep current customers in the hands is at least four times less costly than recruiting a new customer for a company; and that the purpose of modern marketing is to increase the number of the satisfied customers, it will clearly be noticed how vital it is to study the post-purchase consumer behaviors 
and dissatisfactions. In general, the companies should more properly monitor and assess the complaint concept which can be expressed as the feedback notification related to dissatisfaction about purchasing or consumption of a good or a service.

The complaint also offers companies the possibility to establish stronger ties with their customers (Martin, 1997). Despite the fact that the formation of complaints is not such a desirable case, the companies should consider these complaints as feedback providing them an opportunity to be able to notice the errors and shortcomings. It should be believed that the complaints are a valuable source of information for business management and that they provide a valuable opportunity to gather and assess customer information effectively. Consequently, restructuring of the companies at organizational structure and business process level in recent years "in the name of CCM" is a result of this requirement.

In this study were emphasized the concept of "Complaint" and the importance of the Customer Complaints Management applications in improvement of the communication services, which has a significant share in services sector, to offer better quality of services. A survey was conducted considering the assessment of the CCM services by customers in order to determine the degree of the effectiveness of the CCM applications by the GSM companies, such as Turkcell, Vodafone and Avea operating in Turkey. The objectives of this study are as follows:

- To investigate the consumer behaviors about CCM in terms of services provided by GSM companies;

- To ensure that the consumers evaluate the services GSM companies provided in terms of the CCM;

- To determine the similarities and differences of the GSM companies, if any, in terms of CCM services.

The following statistical methods were used to analyze the data obtained from the questionnaires: 1 . Frequency distributions in order to examine the overall distribution of data; 2. Cronbach's alpha based on the principles of $\mathrm{CCM}$ in order to test the reliability of research variables in the questionnaire; 3 . The Chi-square independence test, which is one of non-parametric statistical methods, in order to compare gender with the status of the complainant, and the GSM company with matters of complaints. $4 . t$ test for parametric methods in order to test the difference of the research variables about CCM according to gender. 5. One-way ANOVA in order to reveal differences, if any, in perception of the CCM applications of the GSM companies by the GSM users. 6 . Discriminant analysis method for multivariate parametric methods was applied for the discrimination of the variables defined in terms of GSM companies.

\section{Theoretical Background}

\subsection{Customer Complaints Management (CCM)}

They are Gilly and Hansen (1985) who developed the complaint resolving strategies regarding CCM. Related to the issue, Barlow and Moller (1998) also formed complaint matrices in order to detect the sources of customers' complaints, and to investigate the correlation between the customers' cultural and demographic characteristics and their behavior of complaint.

In their study, Parasuraman and Berry (1997) proved that the customers, who complained about the company and satisfied with their complaints, have a much higher tendency to maintain the same relations with the company compare to those dissatisfied customers.

The purpose of CCM process is to produce the solutions related to the consumer complaints as soon as possible. Considering the studies conducted on this issue, Gerson (1997) revealed the importance of CCM, and focused on the problems encountered by employees, who are first addressed, when implementing the complaint policies and strategies.

Kang et al. (2009) examined the issue within the framework of customer complaints and relationship between customer satisfaction and loyalty and studied the mobile phone industry in China. In their study was indicated that a direct complaint has a positive influence on customer satisfaction.

Considering the e-knowledge-based complaint management, Mjahed and Trike (2009) stated that they put forward a pioneering study in this field. They identified the factors companies need to be successful in the complaint management.

In spite of the fact that there are numerous researches done about the behavior of complain, in Turkey, it is particularly seen most frequently in service sectors. In their performance assessment about CCM, Sarıdald 1 and Sevim (2009) conducted an application study ranging from the service sector to transportation. Evaluating the performance of CCM from the customer perspective, they identified the reasons why it does not work influentially, and they detected the factors reducing the performance of CCM within this process; and 
consequently, rather than complaint management, they investigated the issue within the framework of customers' complaint tendency and the influence of customer satisfaction over the future purchasing tendency of the customers.

Stauss (2002) in brief defined "complaint satisfaction or dissatisfaction refers to the customer's assessment of the company's response to a complaint" (p.174). While the concept is defined as "secondary satisfaction" by Etzel and Silverman (1981) and Oliver (1997); and as "complaint response satisfaction" by Lewis (1983); and as "satisfaction with organization response complaint" by Blodgett and Granbois (1992), "service recovery satisfaction" definition was first used by Boshoff (1999) and de Ruyter and Wetzels (2000). CCM mainly "aiming to retain an existing customer rather than to gain a new one" (Odabaş1, 2001) is "a recovery strategy" (McDougall \& Levesque, 1999, p.7).

$\mathrm{CCM}$ and complaints in changing market conditions enable companies to understand the changing customer needs (Barlow \& Moller, 1998). A well established Complaint Management System is essential for successful companies to manage the customers' needs, to protect their brand, and to achieve their brand value, and to ensure customer loyalty (Doğan \& Erdoğan, 2010). The companies will not only find solutions to the complaints with the help this system they establish, but also they will reach the problem factors, make the necessary adjustments, and will have the opportunity to practice the idea of customer-focused continuous improvement (Naylor, 2003; Odabaşı, 2000).

On the other hand, as the customers are aware how powerful they are in today's competitive environment, they now request more than the price paid for goods and services. They prefer the companies which generate value for them, that is, which listen to their requests and complaints (Çoban, 2005). In one, survey, it was stated that the complaining and dissatisfied customers were more likely to come again to the company compare to those uncomplaining and dissatisfied customers (Barlow \& Moller, 1998). According to another survey, there were strong links between the satisfaction after post-resolved complaints and re-purchase while there was no link between the post-purchase satisfaction and re-purchase (Barıș, 2006). Identifying the reasons of dissatisfactions of the dissatisfied customers and making the necessary adjustments, or ignoring the dissatisfactions of the customers instead are the behaviors which will affect the success of the companies.

Companies can turn the complaints of the customers into an opportunity only through CCM. The main opportunities are as following;

- $\quad$ The complaint just like advertising and sales increasing efforts can be used as a marketing variable creating a feed back (Barış, 2006).

- Holding the light on the factors that reduce the quality of service, the complaint shows what to be done to improve the quality (Bell et al., 2004).

- The complaining customer ensures that the company realizes the operational deficiencies related to the goods or services (Odabaşı, 2000).

- The complaint sends signals to the customers to ensure that they can continue to come to the company.

According Kelleher (1999); evaluation of the customer complaints is extremely significant for three reasons in terms of company: 1. It illuminates the management about the employee performance; 2 . It draws attention to areas in the company for improvement; 3. Complaints are the best indicators of performance in a company.

Within the scope of a study conducted, Stauss and Seidel (1998) suggested nine satisfaction forms related to "complaint satisfaction". And these are adequacy of the problem solution; access: ease of finding a competent, a contact person; friendliness: politeness, courtesy communication style; empathy: willingness to take the customer's perspective, understanding the customer's annoyance, individual complaint handling; individual handling: non-standardized response that is customized to the problem and the wishes of the complainant; effort: visible effort to solve the customer's problem; active feedback: activity to find out the best solution for the customer; notification about delays, feedback about procedures and decisions; reliability: keeping of promises; speed of response: speed of reaction to the complaint, speed at which complaints are resolved.

According to ISO10002: 2004, while handling the customer complaints, the main principles are as follows: transparency; accessibility; responsiveness; objectivity; wages; confidentiality; customer-oriented approach; accountability and continuous improvement. When considered that the concept of satisfaction is a judgment of the customer, it is possible to state that the use of customer-based methods is much more acceptable in evaluating the performance of CCM (Sarıdaldı \& Sevim, 2009). 


\subsection{The Significance of the CCM for GSM Companies in Turkey}

Telephone, which emerged in 19th century, but has still been widely used due to its rapid changes, has become one of the most indispensable tools of the communication sector. In parallel with the rapid development of technology, the communication sector made up pace with this development. Moreover, the rapid development in especially the mobile communication sector and the GSM (Global System for Mobile Communications) operators sectors have led to the growth of the companies operating in the sector and have caused companies to make various innovation.

Beside the growth in the GSM sector in Turkey, the competition between companies has started to increase rapidly. As a result of the competition in the Turkish GSM sector, the target market reached a significant numbers of GSM users/subscribers. According to the data by Information and Communication Technologies Authority (BTK, 2012) compiled by the report of the last quarter of the year 2012, the number of the mobile phone subscribers in Turkey increased to 67.17 million. Consequently, Turkcell has 35.15 million subscribers while Vodafone has 18.81 million, and Avea has 13,21 million subscribers.

The competition has been accelerated with growth aimed infrastructure works diversifying the target market carried out by Avea especially over the last two years; on the other hand, with the diversity of much commercial new service pack released by Vodafone; and marketing strategies by Turkcell to increase the numbers of current users. The consumer behaviors have been strongly influenced by this process (Kızgin, 2008).

Studies on customer satisfaction; customer complaints management practices; And works to improve the quality of service, the customers have had difficulty to decide which GSM company to subscribe, due to the expansion of the good/service ranges offered in the GSM sector; Especially wealth of options and prices offered by the operators; . This sometimes makes the mobile phone subscriber change his GSM operator by moving his phone number from one operator to another constantly or sometimes forces the customer to be a subscriber of more than one operator simultaneously.

In such a competition, it is possible to determine which goods and services of the GSM operators are preferred. It is possible for GSM operator to develop them further, and to be more successful in the sector and to increase their market share by converting these preferences into goods. Therefore, it is essential for the GSM operators to conduct researches considering the reasons why the consumers prefer which goods and services (Kizgin, 2008).

In today's world constantly changing with its values, a company is required to deliver error-free service for the consumer to be successful (Gerson, 1997). It is essential in relations with the customer to listen to them; to speak the same language with customers; to understand their demands and needs; to provide the necessary flexibility in order to reach an agreement; to measure the results and to make the necessary arrangements so as to achieve zero defect level; in other words, to achieve the total customer satisfaction (Ertürk \& Kıyak, 2011). When considered the fact "complaints have a direct impact on the customer satisfaction" (Kang et al., 2009, p.24), as a requirement to compete and maintain the existence, the concept of "customer satisfaction" should be considered necessary; and with the thought that monitoring the dissatisfactions as well as satisfaction is equally a significant means of ensuring customer satisfaction, the GSM companies should focus on the concept of the complaint and should improve the processes in which the complaints are dealt with.

Only some of the objectives of this study are to supply literature scanning on gathering information on the complaints about the GSM goods and the services, investigating the complaint behavior of the GSM customers, and detecting common or/and different complaint behaviors of these companies.

\section{Methodology}

\subsection{Hypotheses}

It is known that in terms of consumer behaviors and of it is impact on purchasing decision, the gender's reaction on purchasing behavior, its level of satisfaction, its post-purchase expectations are rather different respectively. This approach is also a pre-indication of the fact that as consumers the individuals with the different gender state different behaviors regarding the goods and services they purchase to feedback their dissatisfaction. Özdemir and Tokol (2008) indicate that the references and the loyalty the female consumers provided for the companies are influential on sales and the decisions of those companies, due to their biological and sensory differences and their differences during the process of purchasing; and that one of the most decisive factors while establishing the marketing strategies is to know the properties of female nature. The hypotheses can be established as following, taking into account this information.

H1: Consumers' persistence to complain due to their dissatisfaction about goods and services of the GSM companies varies according to gender. 
H2: Perception of CCM performances of the GSM companies varies according to gender.

It is observed that the GSM companies often offer new goods and services to the interests of their consumers in order to increase their market share, and that they also apply a large number of strategies and tactics to promote them due to intense competition environment that both threatens and ensures today's companies improve. Even though, they offer different goods and services, and the goods and services provided should be similar that the technologies they applied in the CCM, and the resolution processes are analogous indicates that the complaints received from the customers are also similar. However, these companies are expected to be different in terms of the complaints about their goods and services owing to the different establishment ages, the stable vision and mission, the number of customers, coverage, adequacy, quality understanding of these companies,. Here are the hypotheses established for that purpose:

H3: The goods and services of the GSM companies complained are different from the other GSM companies.

H4: The complaint management performance of the GSM companies is different from the other GSM companies.

\subsection{Samples and Measures}

Research method consists of the first-hand data, and is based on a survey developed to assess the complaints after the dissatisfaction of GSM subscribers regarding goods and services provided by the GSM companies.

The survey mainly consists of three parts. In the first part, the aim is to compile the demographic and socio-economic conditions of GSM subscribers while it is aimed to gather the complaining experiences of the GSM users. In the second part, the third and last part of the questionnaire aims to measure how the GSM users perceive the CCM principles such as transparency, accessibility, responsiveness, objectivity and customer orientation considered within the framework of ISO10002: 2004. Considering the fact that the information related to implementations of GSM company regarding accountability, privacy, continuous improvement, and wages can only be obtained from the GSM companies; and that there are bureaucratic barriers to obtain this information; and that customers should be the only inspectors of concept of complaints satisfaction, these principles were not taken into consideration.

The survey was administered via the Internet, and invitation links to participate the survey were sent to the participants' e-mail addresses at random. The sampling Formula size of the questionnaires included 384 persons, with Populations with an unknown status (Özdamar, 2003), with $\mathrm{p}=0.5, \mathrm{q}=0.5, \mathrm{~d}=0.05$ and $5 \%$ margin of error. The surveys were expected to return for nearly 3 months, and answers were eliminated of the participants, who deliberately did not answer an critical survey question, and/or left a large portion of the survey questions empty, and/or sent more than one questionnaire. A total of 432 questionnaires were assessed.

In terms of CCM principles considered within the scope of ISO 1002: 2004, thirteen (13) propositional questions were directed in order to determine to what extend the GSM users perceive the services provided by the GSM companies. GSM users were directed four (4) propositional questions to determine how their "complaints" behavior would be in case they encountered customer dissatisfaction as GSM subscribers. A 5-point Likert-type scale was used as the scale of the survey as follows: 1 . I totally disagree; 2 . I disagree; 3 . I less agree; 4. I agree, and 5. I totally agree. However, since two questions related to general perception of the complaints were thought not to be understood well, agreed upon the value of Cronbach's alpha, they were taken off the study.

\section{Findings}

\subsection{Participants' Findings}

Table 1 indicates the demographic and social status of the participants. Accordingly, 47,2 (\%) of the participants were worker-civil servants; 43.1 (\%) were college graduates; $56.9(\%)$ were females while the income level of $27.8(\%)$ was in the range between 1500 and $3000 \mathrm{TL}$, and $45.8(\%)$ were between the ages of 25 and 35 .

Table 1. Indicates the demographic and social status of the participants

\begin{tabular}{lccccc}
\hline Education & Frequency & Percent(\%) & Age & Frequency & Percent(\%) \\
\hline Primary-intermediate school & 0 & 0 & $18-24$ & 120 & 27.8 \\
High school & 126 & 29.2 & $25-35$ & 198 & 45.8 \\
Vocational College & 126 & 29.2 & $36-45$ & 78 & 18.1 \\
\hline
\end{tabular}




\begin{tabular}{|c|c|c|c|c|c|}
\hline Bachelor & 186 & 43.1 & $46-59$ & 36 & 8.3 \\
\hline Graduate(MA, Doctoral) & 102 & 23.6 & $>60$ & 0 & 0 \\
\hline Total & 432 & 100 & Total & 432 & 100 \\
\hline Occupation & & & Income & & \\
\hline Student & 96 & 22.2 & $<630$ & 102 & 23.6 \\
\hline Self-employed-Tradesman & 96 & 22.2 & $\begin{array}{c}\text { TL } \\
631- \\
1500\end{array}$ & 114 & 26.4 \\
\hline Worker - Civil Servants & 204 & 47.2 & $\begin{array}{c}\text { TL } \\
1501- \\
3000\end{array}$ & 120 & 27.8 \\
\hline Retired & 6 & 1.4 & $\begin{array}{c}\text { TL } \\
3001- \\
5000\end{array}$ & 72 & 16.7 \\
\hline Housewife & 18 & 4.2 & $\begin{array}{c}\mathrm{TL} \\
>5001 \\
\mathrm{TL}\end{array}$ & 24 & 5.6 \\
\hline No reponse & 12 & 2.8 & Total & 432 & 100 \\
\hline Total & 432 & 100 & & & \\
\hline \multicolumn{6}{|l|}{ Gender } \\
\hline Female & 246 & 56.9 & & & \\
\hline Male & 186 & 43.1 & & & \\
\hline Total & 432 & 100 & & & \\
\hline
\end{tabular}

Table 2 shows information about the complaint experiences by the GSM users about the GSM Products and Services. It was observed that Avea Users complained their company with the highest percentage of 47.2 as of the complaints directed within last six months; that the participant, with a percentage of 69.4 , opted for the option "I have complained and sought for my right" which indicates the persistence"; and that $30.6 \%$ of the complaints were "tariff-related issues".

Table 2. The findings of complaints

\begin{tabular}{|c|c|c|c|c|c|}
\hline $\begin{array}{l}\text { Complaints directed to the } \\
\text { GSM companies within last } \\
\text { six months }\end{array}$ & Frequency & Percent $(\%)$ & $\begin{array}{l}\text { Issues of the } \\
\text { complaints } \\
\text { directed }\end{array}$ & Frequency & Percent $(\%)$ \\
\hline Avea & 204 & 47.2 & $\begin{array}{l}\text { Problems related } \\
\text { to tariffs }\end{array}$ & 132 & 30.6 \\
\hline Turkcell & 126 & 29.2 & $\begin{array}{l}\text { Problems related } \\
\text { to bill }\end{array}$ & 84 & 19.4 \\
\hline Vodafone & 102 & 23.6 & $\begin{array}{l}\text { Problems related } \\
\text { to coverage }\end{array}$ & 66 & 15.3 \\
\hline Total & 432 & 100.0 & $\begin{array}{l}\text { Slow processing } \\
\text { of the call center }\end{array}$ & 18 & 4. 2 \\
\hline situation of make & & & Disposal of & 24 & 5.6 \\
\hline
\end{tabular}




\begin{tabular}{|c|c|c|c|c|c|}
\hline complainant & & & $\begin{array}{l}\text { unnecessary short } \\
\text { messages (SMS) }\end{array}$ & & \\
\hline $\begin{array}{l}\text { I have complained and } \\
\text { sought for my right }\end{array}$ & 300 & 69.4 & Other & 24 & 5.6 \\
\hline $\begin{array}{l}\text { I have complained and be } \\
\text { displeased at, at last } \\
\text { changed my GSM company }\end{array}$ & 126 & 29.2 & Unanswered & 84 & 19.4 \\
\hline Unanswered & 6 & 1.4 & Total & 432 & 100.0 \\
\hline Total & 432 & 100.0 & & & \\
\hline
\end{tabular}

\subsection{Non-Parametric Test Findings}

The complaints of the GSM users concerning their dissatisfaction about the purchased products and services were given by gender (for $\mathrm{H} 1$ hypothesis testing) in table 3 . It was understood that the complaints of participants or their persistence in complaining within last 6 months did not change in terms of gender factor $(\mathrm{P}=$ $0.146>0.05)$; and that H1 hypothesis was not supported on this issue.

Table 3. The findings the complaints of participants by gender

\begin{tabular}{|c|c|c|c|c|c|c|}
\hline \multirow[b]{2}{*}{ Gender } & \multicolumn{2}{|c|}{ Case of the complaints directed within last six months } & \multirow[b]{2}{*}{ Total } & \multirow[b]{2}{*}{$\begin{array}{c}\text { Pearson } \\
\text { Chi-square }\end{array}$} & \multirow[b]{2}{*}{ Df. } & \multirow[b]{2}{*}{ P-value } \\
\hline & $\begin{array}{l}\text { I have complained and } \\
\text { sought for my right }\end{array}$ & $\begin{array}{l}\text { I have complained and be } \\
\text { displeased at, at last changed my } \\
\text { GSM company }\end{array}$ & & & & \\
\hline Female & 180 & 66 & 246 & 2,111 & 1 & 0,146 \\
\hline Male & 120 & 60 & 180 & & & \\
\hline Total & 300 & 126 & 426 & & & \\
\hline
\end{tabular}

For H3 hypothesis testing, in table 4 were given the findings compiled in order to search for the correlation between the subjects of the complaints directed to the GSM companies. Accordingly, it was seen that when the complaint issues were compared with the complained GSM companies, the Chi-square test was significant ( $\mathrm{P}=$ $0,000(<) 0,001)$; and that $\mathrm{H} 3$ hypothesis was supported on this issue,

Table 4. The findings compiled in order to search for the correlation between the subjects of the complaints directed to the GSM companies

\begin{tabular}{|c|c|c|c|c|c|c|c|}
\hline \multirow{2}{*}{ Complaint Subjects } & \multicolumn{4}{|c|}{ Complaints directed to the GSM companies } & \multirow{2}{*}{$\begin{array}{c}\text { Pearson } \\
\text { Chi-square }\end{array}$} & \multirow{2}{*}{ Df. } & \multirow{2}{*}{$\begin{array}{c}\text { P-valu } \\
\text { e }\end{array}$} \\
\hline & Turkcell & Vodafone & Avea & Total & & & \\
\hline Problems related to tariffs & 60 & 42 & 30 & 132 & & & \\
\hline Problems related to bill & 24 & 24 & 36 & 84 & & & \\
\hline Problems related to coverage & 48 & 12 & 6 & 66 & & & \\
\hline Slow processing of the call & 12 & 6 & 0 & 18 & & & \\
\hline center & & & & & 61.728 & 10 & 0.000 \\
\hline $\begin{array}{l}\text { Disposal of unnecessary } \\
\text { short messages (SMS) }\end{array}$ & 6 & 6 & 12 & 24 & & & \\
\hline Other & 12 & 12 & 0 & 24 & & & \\
\hline Total & 162 & 102 & 84 & 348 & & & \\
\hline
\end{tabular}


The reliability values of the questions asked in accordance with the principles of CCM were given in table 5 . Cronbach's alpha value was noticed above 0.7 which is considered adequate for a social science research. Additionally, the sampling adequacy can be considered good as the Kaiser-Meyer-Olkin Test for sampling adequacy was 0.838 and $\mathrm{P}$ value was $0.000<0.05$.

Table 5. The findings of the research variables

\begin{tabular}{|c|c|c|c|c|c|c|}
\hline CCM Variables & Frequency & Mean & Df & $\begin{array}{c}\mathrm{CCM} \\
\text { Principles }\end{array}$ & Mean & $\begin{array}{c}\text { Cronbach } \\
\text { Alpha }\end{array}$ \\
\hline $\begin{array}{l}\text { To return to the customer regarding } \\
\text { the complaints }\end{array}$ & 420 & 2.857 & 1.087 & Responsiveness & 3.087 & 0.732 \\
\hline $\begin{array}{l}\text { To follow up the complaint records } \\
\text { with SMS, telephone and e-mail }\end{array}$ & 432 & 2.889 & 1.186 & & & \\
\hline $\begin{array}{l}\text { To analyze the complaint by } \\
\text { applying to an authorized personnel } \\
\text { at the first stage }\end{array}$ & 426 & 2.775 & 1.117 & & & \\
\hline $\begin{array}{l}\text { To return to the customer as soon as } \\
\text { possible about the complaints }\end{array}$ & 432 & 3.819 & 1.086 & & & \\
\hline $\begin{array}{l}\text { To reach an authorized personnel } \\
\text { about the complaints as soon as } \\
\text { possible }\end{array}$ & 432 & 2.458 & 1.054 & Accessibility & 2,944 & 0.713 \\
\hline $\begin{array}{l}\text { The ease to access to the complaints } \\
\text { system }\end{array}$ & 432 & 2.653 & 1.134 & & & \\
\hline $\begin{array}{l}\text { To know where and how to make the } \\
\text { complaint }\end{array}$ & 432 & 3.722 & 1.058 & & & \\
\hline $\begin{array}{l}\text { To have a clear and well defined } \\
\text { process in order to phase in the } \\
\text { complaint }\end{array}$ & 420 & 3.014 & 1.166 & Visibility & 3.030 & 0.822 \\
\hline $\begin{array}{l}\text { To indicate the way/ways to submit a } \\
\text { complaint }\end{array}$ & 414 & 3.072 & 1.109 & & & \\
\hline $\begin{array}{l}\text { the know-how adequacy of the } \\
\text { authorized personnel who was } \\
\text { reported the complaint }\end{array}$ & 426 & 3.028 & 1.035 & Objectivity & 2.920 & 0.786 \\
\hline $\begin{array}{l}\text { The accuracy of official knowledge } \\
\text { of the authorized personnel who is to } \\
\text { evaluate the complaint }\end{array}$ & 420 & 2.800 & 1.024 & & & \\
\hline $\begin{array}{l}\text { Satisfaction with the efforts provided } \\
\text { during the complaint resolution } \\
\text { process }\end{array}$ & 420 & 2.686 & 1.037 & $\begin{array}{l}\text { Customer-focused } \\
\text { approach }\end{array}$ & 3.193 & 0.708 \\
\hline $\begin{array}{l}\text { Positive aspects of the established } \\
\text { and well-performing complaint } \\
\text { process in terms of service quality }\end{array}$ & 432 & 3.708 & 1.149 & & & \\
\hline
\end{tabular}

\subsection{Parametric Test Findings}

The Skewness and Kurtosis values can be applied for questioning the validity of the assumption of normal 
distribution, which is one of the significant assumptions, in order to apply t Test, ANOVA and Discriminant Analysis of Parametric Methods. These values are required to be in between $-2<\mathrm{X}<+2$ (Şencan, 2002). In the case of a violation, in this matter, according to the central limit theory, the data are assumed to meet the normal distribution condition as the number of the samples is over 40 (Stat trek, 2012; Statsoft, 2012; Lumley et al., 2002). In the study, it was seen that there was no variable violating the normal distribution assumption.

While seen that the perceptional differences about the CCM variables given in table 6 had a correlation with the gender, three other variables did not have any perceptional differences related to gender.

Table 6. The findings to be compared CCM variables by gender

\begin{tabular}{|c|c|c|c|}
\hline $\mathrm{CCM}$ variables & $\begin{array}{c}\text { Female } \\
\text { Mean } \\
(\mathrm{df})\end{array}$ & $\begin{array}{l}\text { Male } \\
\text { Mean } \\
\text { (df) }\end{array}$ & t-value \\
\hline $\begin{array}{l}\text { To have a clear and well defined } \\
\text { process in order to phase in the } \\
\text { complaint }\end{array}$ & $\begin{array}{c}3.20 \\
(1.032)\end{array}$ & $\begin{array}{c}2.90 \\
(1.188)\end{array}$ & $2.771 * \diamond$ \\
\hline $\begin{array}{l}\text { To reach an authorized personnel } \\
\text { about the complaints as soon as } \\
\text { possible }\end{array}$ & $\begin{array}{l}2.61 \\
(1.011)\end{array}$ & $\begin{array}{l}2.26 \\
(1.080)\end{array}$ & $3.476^{*}$ \\
\hline $\begin{array}{l}\text { the know-how adequacy of the } \\
\text { authorized personnel who was } \\
\text { reported the complaint }\end{array}$ & $\begin{array}{c}3.25 \\
(0.970)\end{array}$ & $\begin{array}{c}2.74 \\
(1.049)\end{array}$ & $5.173^{* *}$ \\
\hline $\begin{array}{l}\text { The accuracy of official knowledge } \\
\text { of the authorized personnel who is to } \\
\text { evaluate the complaint }\end{array}$ & $\begin{array}{l}2.97 \\
(1.002)\end{array}$ & $\begin{array}{l}2.58 \\
(1.012)\end{array}$ & $3.979 * * \diamond$ \\
\hline $\begin{array}{l}\text { To return to the customer as soon as } \\
\text { possible about the complaints }\end{array}$ & $\begin{array}{l}3,93 \\
(1.070)\end{array}$ & $\begin{array}{l}3,68 \\
(1.092)\end{array}$ & $2.377^{*}$ \\
\hline $\begin{array}{l}\text { To follow up the complaint records } \\
\text { with SMS, telephone and e-mail }\end{array}$ & $\begin{array}{l}3.07 \\
(1.137)\end{array}$ & $\begin{array}{l}2.65 \\
(1.209)\end{array}$ & $3.769^{* *}$ \\
\hline $\begin{array}{l}\text { The ease to access to the complaints } \\
\text { system }\end{array}$ & $\begin{array}{l}2.78 \\
(1.073)\end{array}$ & $\begin{array}{l}2.48 \\
(1.191)\end{array}$ & $3.737^{* *}$ \\
\hline $\begin{array}{l}\text { Satisfaction with the efforts provided } \\
\text { during the complaint resolution } \\
\text { process }\end{array}$ & $\begin{array}{l}2.85 \\
(0.939)\end{array}$ & $\begin{array}{l}2.47 \\
(1.121)\end{array}$ & $3.715^{* * \diamond}$ \\
\hline $\begin{array}{l}\text { To know where and how to make the } \\
\text { complaint }\end{array}$ & $\begin{array}{l}3.54 \\
(1.064)\end{array}$ & $\begin{array}{l}3.97 \\
(1.002)\end{array}$ & $-4.276^{* * \diamond}$ \\
\hline $\begin{array}{l}\text { Positive aspects of the established } \\
\text { and well-performing complaint } \\
\text { process in terms of service quality }\end{array}$ & $\begin{array}{l}3.56 \\
(1.063)\end{array}$ & $\begin{array}{l}3.90 \\
(1.231)\end{array}$ & $-3.095^{*}$ \\
\hline
\end{tabular}

$\diamond$ Variances is not homogeneous; ${ }^{*} \mathrm{p}<0.05 * * \mathrm{p}<0.001$.

Note: P-values of the other three complaint-variables were not stated in table 6 as they were not significant.

$\mathrm{H} 2$ hypothesis formulated in correlation with this is acceptable. When the variables were grouped in accordance with the CCM principles, significant differences related to gender were found out in the complaint perceptions in all the variables constituting the principles of accessibility, customer-orientedness, and objectivity.

Within the scope of one-way ANOVA test conducted, related to the CCM variables involved in the research, 
while no significant difference was reached between the mean scores of variables of "Reaching an authorized person concerned with the complaint as soon as possible" and "Satisfaction with the efforts supplied during the complaint resolution process", the mean scores of all other research variables, considering three GSM companies, had a significant difference.

H4 Hypothesis formulated for this issue was accepted. A multiple comparison analysis was not applied on the results of ANOVA (Post-Hoc) as Discriminant Analysis was applied in order to determine the distinguishing hallmarks of the 11 variables, which have significant differences, according to the GSM companies.

Table 7. The findings to be compared CCM variables by complaints directed to the GSM companies

\begin{tabular}{|c|c|c|c|c|}
\hline \multirow{3}{*}{ CCM Variables } & \multicolumn{4}{|c|}{ Complaint Directed to the GSM Operator } \\
\hline & \multicolumn{2}{|c|}{ Levene } & \multicolumn{2}{|c|}{ ANOVA } \\
\hline & Statistic & $\begin{array}{c}\mathrm{P} \\
\text { value }\end{array}$ & $\begin{array}{c}\mathrm{F} \\
\text { value }\end{array}$ & $\begin{array}{c}\mathrm{P} \\
\text { value }\end{array}$ \\
\hline To return to the customer regarding the complaints & 8,159 & $0,000^{\diamond}$ & 9,689 & $0,000^{* *}$ \\
\hline $\begin{array}{l}\text { To follow up the complaint records with SMS, telephone and } \\
\text { e-mail }\end{array}$ & 6,940 & $0,001^{\diamond}$ & 4,531 & $0,011^{*}$ \\
\hline $\begin{array}{l}\text { To analyze the complaint by applying to an authorized } \\
\text { personnel at the first stage }\end{array}$ & 8,420 & $0,000^{\diamond}$ & 9,394 & $0,000 * *$ \\
\hline $\begin{array}{l}\text { To return to the customer as soon as possible about the } \\
\text { complaints }\end{array}$ & 18,104 & $0,000^{\diamond}$ & 13,895 & $0,000 * *$ \\
\hline $\begin{array}{l}\text { To reach an authorized personnel about the complaints as } \\
\text { soon as possible }\end{array}$ & 2,328 & 0,099 & 0,071 & 0,932 \\
\hline The ease to access to the complaints system & 8,319 & $0,000^{\diamond}$ & 3,668 & $0,026^{*}$ \\
\hline To know where and how to make the complaint & 32,937 & $0,000^{\diamond}$ & 6,389 & $0,002 *$ \\
\hline $\begin{array}{l}\text { To have a clear and well defined process in order to phase in } \\
\text { the complaint }\end{array}$ & 8,736 & $0,000^{\diamond}$ & 14,615 & $0,000 * *$ \\
\hline To indicate the way/ways to submit a complaint & 10,633 & $0,000^{\diamond}$ & 17,012 & $0,000 * *$ \\
\hline $\begin{array}{l}\text { The know-how adequacy of the authorized personnel who } \\
\text { was reported the complaint }\end{array}$ & 8,887 & $0,000^{\diamond}$ & 8,166 & $0,000 * *$ \\
\hline $\begin{array}{l}\text { The accuracy of official knowledge of the authorized } \\
\text { personnel who is to evaluate the complaint }\end{array}$ & 5,708 & $0,004^{\diamond}$ & 4,599 & $0,011 * *$ \\
\hline $\begin{array}{l}\text { Satisfaction with the efforts provided during the complaint } \\
\text { resolution process }\end{array}$ & 7,225 & $0,001^{\diamond}$ & 1,199 & 0,302 \\
\hline $\begin{array}{l}\text { Positive aspects of the established and well-performing } \\
\text { complaint process in terms of service quality }\end{array}$ & 16,282 & $0,000^{\diamond}$ & 8,962 & $0,000 * *$ \\
\hline
\end{tabular}

\subsection{Discriminant Analysis Findings}

Assumptions of Discriminant Analysis, Normal distribution hypotheses;

- Normal distribution condition; Normal distribution condition suitability required in order to apply both $t$ test and ANOVA was tested and discriminant analysis findings and there is no such indication violating this condition.

- Another assumption required for application of linear discriminant Analysis is that group covariance matrices are equal to each other. Quadratic Discriminant Analysis must be applied when this condition is not achieved (Özdamar, 1999). Multiple quadratic Discriminant Analysis is possible when there are at least three 
clusters, in other words to say when there are three clusters and two separation functions (Nakip, 2003).

- Another major assumption of the discriminant analysis is the lack of multicollinearity link between the variables. It is concluded that there is no multicollinearity, due to the lack of a correlation greater than 0.70 in the matrix given in table 9 (Akgül \& Çevik, 2003).

- A multiple Discriminant Analysis in terms of complained GSM companies was applied to discriminate the 11 significant variables resulted from ANOVA analysis of CCM variables. Box's M testing the equality of covariance matrices was 330.177 and the probability value was $\mathrm{P}(0.158)>0.05$, the covariance matrices was concluded to be equal at a 5\% error level. Accordingly, the linear discriminant Analysis can be used.

- There should not exist an outlier value in data. In order to determine and eliminate the outlier values during the Discriminant Analysis, critical Mahalanobis D2 value was at 16.81 with $99 \%$ reliability while s.d. was 6 . As there did not exist any data which has D2 greater than this critical value during the discrimination analysis, there was no need to eliminate this value.

- There must be 30 or 4-5 times the amount of data for each independent variable: while average 330 data are sufficient for 11 variables included in the survey, 432 survey data meets this criterion.

Discriminant Analysis

In this study, there were a total of 13 variables considered as CCM variables. However, under the terms of the ANOVA test, two variables with insignificant difference in terms of the GSM companies were taken out of the Discriminant Analysis. In total, 11 variables were considered during the Discriminant Analysis. Stepwise Discriminant Analysis was used in order to best estimate which of these variables shows the characteristics of the complained GSM companies.

Stepwise Discriminant Analysis must be applied when the number of the variables exceeds the required number during the discriminant analysis, or when it is required to separate the wanted variables within the set of data (Özdamar, 1999).

In table 8 were given the Discriminant Analysis results obtained from three complained GSM companies. According to these data, two discriminant functions were obtained. As the probability value of these two discriminant functions is $(0.00001<0.05)$, It was seen that discriminant function is a statistically significant function; and that it can be applied in discrimination process.

Table 8. Canonical discriminants functions

\begin{tabular}{cccccccc}
\hline Functions & $(\lambda)$ & $\begin{array}{c}\text { Variance } \\
(\%)\end{array}$ & $\begin{array}{c}\text { Canonical } \\
\text { Correlation }\end{array}$ & $\begin{array}{c}\text { Wilks' } \\
\text { Lambda }(\Lambda)\end{array}$ & Chi-square & Df. & $\begin{array}{c}P \\
\text { value }\end{array}$ \\
\hline 1 & 0,234 & 61,3 & 0,435 & 0,706 & 127,357 & 12 & $0,000^{*}$ \\
2 & 0,147 & 38,7 & 0,358 & 0,872 & 50,376 & 5 & $0,000^{*}$ \\
\hline
\end{tabular}

$*$ p $<0.001$.

While testing the significance of the discriminant functions and coefficients used in the Discriminant Analysis, Wilk's lambda value is used. Wilk's lambda value is a value between zero and one. The smaller this value is, the greater the distinguishing power of the model will be (Akgül \& Çevik, 2003). In addition, the variance indicated in the first function was $61.3 \%$, and the variance of the second function was $38.7 \%$.

Table 9. Correlation matrix of discriminant analysis variables

\begin{tabular}{|c|c|c|c|c|c|c|c|c|c|c|c|}
\hline $\mathrm{CCM}$ variables & 1 & 2 & 3 & 4 & 5 & 6 & 7 & 8 & 9 & 10 & 11 \\
\hline To have a clear & 1.00 & 0.631 & 0.527 & 0.534 & 0.497 & 0.237 & 0.469 & 0.440 & 0.516 & 0.201 & 0.285 \\
\hline and well & & & & & & & & & & & \\
\hline defined process & & & & & & & & & & & \\
\hline in order to & & & & & & & & & & & \\
\hline phase in the & & & & & & & & & & & \\
\hline
\end{tabular}




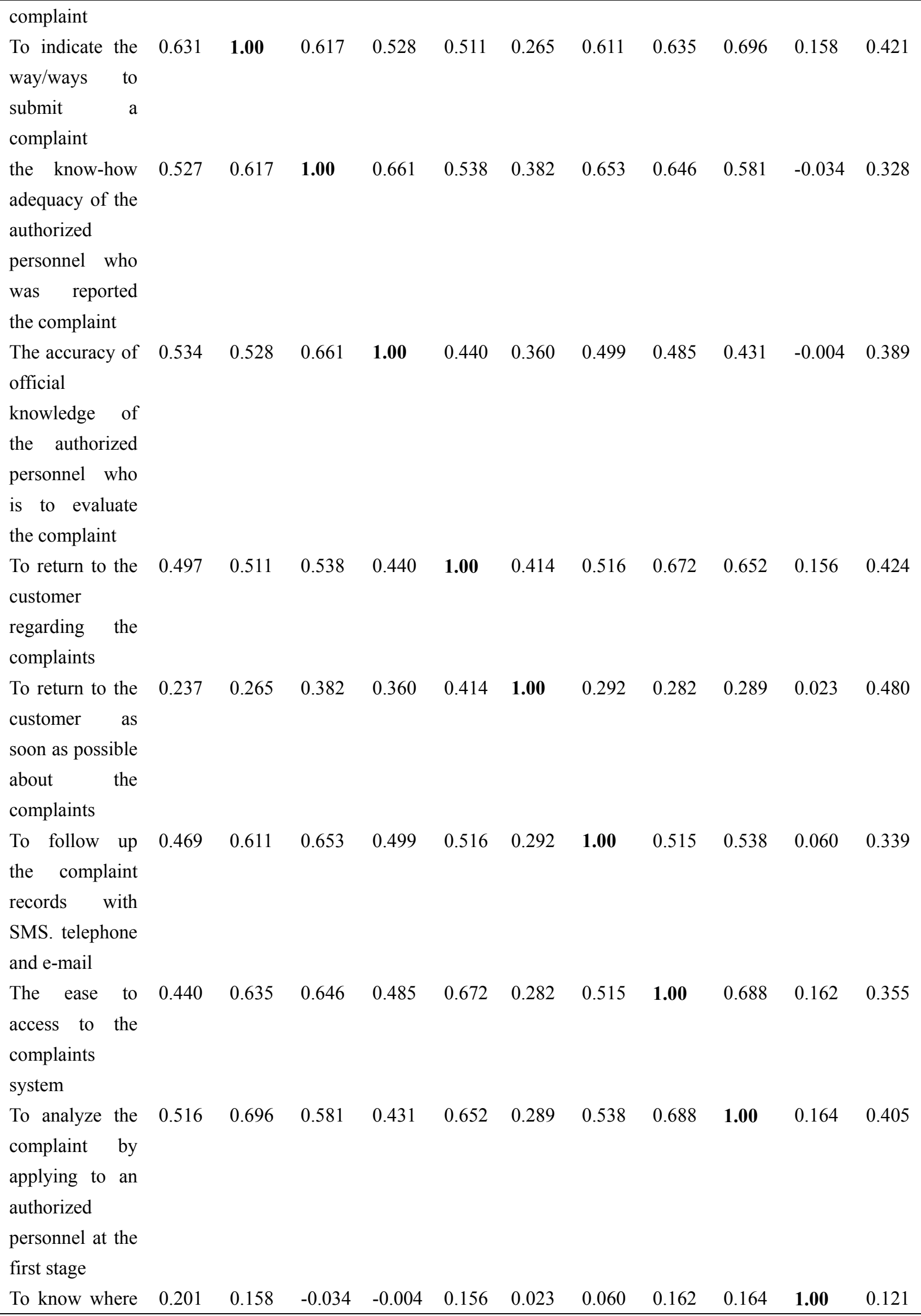




and how to
make the
complaint
$\begin{aligned} & \text { Positive aspects } \\ & \text { of the }\end{aligned}$ the
established and
well-performing
complaint
process in terms
of service
quality

While constituting the discriminant model. A variable should have an equal or greater value than F-input value to participate in the model; a variable to be taken out of the model must have an equal value than F-output value(Özdamar. 1999). In this context. while constituting the stepwise discriminant model. The F-input value was 0.05 . and F-output value was 0.10 which was twice the value when SPSS preliminary value was applied. The number of the variables involved in the model dropped to six. Afterwards. after removing the variables obtained from the system. the Discriminant Analysis was applied once again to see that the result did not change.

Discriminant loads indicate the contribution of independent variables to the model (Churchill. 1999). The loads of the variables thought to be a significant contribution to the model. both negative and positive. must be 0.3 or above (Whitelock \& Jobber. 2004). It was observed that this rule was not violated but one variable $(-0.263)$. As a result of implementing the second phase of Discriminant Analysis. It was decided to keep the variable in this model. The structure matrix of these variables obtained was given in table 10.

Table 10. Structure matrix

\begin{tabular}{lcc}
\hline \multirow{2}{*}{ CCM Variables } & \multicolumn{2}{c}{ Discriminant } \\
\cline { 2 - 3 } & 1 & 2 \\
\hline To return to the customer as soon as possible about the complaints & $0.422\left(^{*}\right)$ & 0.248 \\
To follow up the complaint records with SMS. telephone and e-mail & $0.334\left(^{*}\right)$ & 0.123 \\
To know where and how to make the complaint & $-0.263\left(^{*}\right)$ & -0.206 \\
To indicate the way/ways to submit a complaint & 0.063 & $0.784\left(^{*}\right)$ \\
To have a clear and well defined process in order to phase in the complaint & -0.190 & $0.641\left(^{*}\right)$ \\
To analyze the complaint by applying to an authorized personnel at the first & -0.402 & $0.422\left(^{*}\right)$ \\
stage & & \\
\hline
\end{tabular}

When the table 11 of group averages was analyzed. concerning the complaints directed. it was observed that Avea had a distinguishing difference (0.566) compare to other GSM companies; and that Vodafone had the highest value $(0.583)$ in the second discriminant function. It can be stated that in two respective discriminant functions. Turkcell did not have any group average superior to the other GSM companies. 
Table 11. Functions at group centroids

\begin{tabular}{cccc}
\hline Complaint Directed to the GSM Operators & \multicolumn{2}{c}{ Discriminant Function } \\
\cline { 2 - 4 } & 1 & 2 \\
\hline Avea & 0.566 & 0.014 \\
Turkcell & -0.392 & -0.434 & 0.583 \\
Vodafone & -0.432 & 0.53
\end{tabular}

Classification coefficients are calculated separately for each group and the classification process of the observation. According to the independent variables, it will be determined by the score the observation will obtain. The coefficients obtained for this purpose were given as the classification function coefficients in table 12.

Table 12. Standardized canonical discriminant function coefficients

\begin{tabular}{|c|c|c|c|}
\hline \multirow[t]{2}{*}{ CCM Variables } & \multicolumn{3}{|c|}{$\begin{array}{l}\text { Complaint Directed to the GSM } \\
\text { Operators }\end{array}$} \\
\hline & Avea & Turkcell & Vodafone \\
\hline To clear and defined process related to phasing in the complaint & -0.072 & 0.219 & 0.478 \\
\hline To return to the customer as soon as possible about the complaints & 2.907 & 2.421 & 2.514 \\
\hline To follow up the complaint records with SMS. telephone and e-mail & 0.864 & 0.630 & 0.088 \\
\hline $\begin{array}{l}\text { To analyze the complaint by applying to an authorized personal at the } \\
\text { first stage }\end{array}$ & -0.588 & 0.381 & 0.323 \\
\hline To know where and how to make the complaint & 3.383 & 3.689 & 3.313 \\
\hline To indicate the way/ways to submit a complaint & 1.245 & 0.213 & 1.179 \\
\hline Constant & -15.366 & -14.613 & -15.974 \\
\hline Fisher's linear discriminant functions & & & \\
\hline
\end{tabular}

Accurate estimate. carried out through Discriminant Analysis in accordance with the income groups. is expected to be $25 \%$ more than the Proportional Chance Criterion (PCC) (Li et al.. 2007). Proportional Chance Criterion by group numbers; the sum of possibilities for priority of the groups was calculated as $(0.4192+0.3392+0.2422=0.349)$. Accordingly, as the $0.349 *(1.25)=0.433$ value is less than the correct classification rate of 0.57 . The classification is considered to be correct.

Tablo 13. The probabilities of groups

\begin{tabular}{lcccc} 
& Complaint Directed to the GSM Operators & Prior & \multicolumn{2}{c}{ F value } \\
\cline { 3 - 5 } & & 0.419 & 156 & 156.000 \\
\hline Avea & 0.339 & 126 & 126.000 \\
Turkcell & 0.242 & 90 & 90.000 \\
Vodafone & 1.000 & 372 & 372.000 \\
Total & & & Weighted \\
\hline
\end{tabular}


Table 14. The classify results

\begin{tabular}{ccccccc}
\hline & \multirow{2}{*}{ Complaint Directed to the GSM Operators } & \multicolumn{4}{c}{ Group member of be estimated } \\
\cline { 4 - 6 } & & & Avea & Turkcell & Vodafone & Total \\
\hline Estimate & F. & Avea & 120 & 30 & 24 & 174 \\
& & Turkcell & 60 & 54 & 12 & 126 \\
& & Vodafone & 36 & 24 & 36 & 96 \\
& \multirow{2}{*}{$\%$} & Avea & 69.0 & 17.2 & 13.8 & 100.0 \\
& Turkcell & 47.6 & 42.9 & 9.5 & 100.0 \\
& Vodafone & 37.5 & 25.0 & 37.5 & 100.0 \\
\hline
\end{tabular}

a) $53.0 \%$ of original grouped cases correctly classified.

b) $53.0 \%$ of cross-validated grouped cases correctly classified.

In addition. the Press's Q statistic can be used to test the power of the discrimination function(Hair. et al.; Chan. 2005). As below:

$$
Q=[N-(n K)]^{2} / N(k-1)
$$

Where Formula: $\mathrm{N}=432$. $\mathrm{n}=$ correct classification number $(0.53 * 432)=229$; and $\mathrm{k}$ (the number of groups $)=3$. As Press's Q=75.2 $>9.21$ (chi-square table 0.99.2) is greater than Press's Formula of Q. the classification can be stated to have a higher statistical significance than the Chance Criterion.

\section{Discussion}

By the findings compiled. in this study were analyzed the CCM implementations at GSM service. which is the most powerful and the most common representative, and which is one of the most crucial areas of communication service sectors in particularly Turkey. In this study was tried to explain how the customers have perceived the processes of CCM that the GSM companies applied to their customers.

To compare other GSM companies, it is possible to indicate that related to the complaints directed to Avea. The customer perception has a higher level of satisfaction. positive in terms of the variables of "return to the customer regarding the complaints as soon as possible". and of "follow up the complaint records with SMS. telephone and e-mail". But it can be indicated that the customer perception has a higher level of dissatisfaction. negative in terms of the variable "not to know where and how to make the complaint".

The distinctive function is the second function in terms of the variables: "indication of the way/ways to submit a complaint". "To have a clear and well defined process in order to phase in the complaints" and "resolution of the complaint by applying to authorized personnel at the first stage". Vodafone has a distinguishing superiority in this function. Accordingly, it can be indicated that the company performance. which the customers perceived about this company in terms of the complaints stated in these variables. is better than that of the other companies. Although Turkcell has a market share based upon long years and has more complaints directed than that of the other companies. it is noticed that it has no superiority over the other companies in terms of perception of its complaint assessment performance.

\section{Conclusion}

It is better understood how valuable the customer satisfaction is in order to maintain the customer in especially today's competition conditions in which it is cheaper to keep the existing customers than to gain new ones. Especially the indifference to the complaints has the highest share among the reasons of customers to quit a company, the efforts provided in this respect should be perceived as a necessity to confront today's competitive environment. In this context, it should not be ignored that the customer complaints as the feedbacks from customers are extremely valuable for a company to notice its shortcomings and errors.

CCM processes should be defined by all the companies declared for the customers explicitly, and CCM processes should be shortened and accelerated as possible. Most importantly the idea "the complaint is a valuable source of information" should be institutionalized in the organization rather than understanding "the complaining customer is the problematic customer". It should be understood more adequately that better management processes can be achieved with more complaint management processes. 


\section{Limitations and Future Research}

In addition to the performance perception of customer complaints taken into consideration in the study. the measuring of the internal applications of the GSM companies. such as accountability; privacy; wage; continuous improvement, which were not taken into consideration. is essential in order to see the CCM performance as a whole. With an integrated approach the real CCM performances will be reached by constantly monitoring the performances of the companies related to both the perceptions on the client-side and the CCM applications provided by these companies. Such study matters to be conducted on a larger scale and with such a continuity were left to the researchers who want to conduct a research on this issue. In this study, attention was drawn only to the complaint behaviors and the perception of the CCM applications by the customers.

\section{References}

Akgül, A., \& Çevik, O. (2003). İstatistiksel Analiz Teknikleri SPSS'te İsletme Yönetimi Uygulamaları. Ankara: Emek Ofset.

Barış, G. (2006). Kusursuz Müşteri Memnuniyeti İçin Şikâyet Yönetimi. MediaCat Kitapları. İstanbul.

Barlow, J., \& Moller. C. (1998). Her Şikâyet Bir Armağandır (Çev: Günhan Günay). Rota Yayınları, Istanbul.

Bell, S. J., Mengüç, B., \& Stefani, S. L. (2004). When Customers disappoint: A model of relational internal marketing and customers complaints. Journal of the Academy of Marketing Science, 32(2), 112-126. http://dx.doi.org/10.1177/0092070303261467

Blodgett, J. G., \& Granbois, D. H. (1992). Toward an integrated conceptual model of consumer complaining behavior. Journal of Consumer Satisfaction. Dissatisfaction and Complaining Behaviour, 5, 95-103. Retrieved from http://lilt.ilstu.edu/staylor/csdcb/articles/volume5/blodgett\%20et\%20al\%201992.pdf

Boshoff, C. (1999). An instrument to measure satisfaction with transaction-specific service recovery. Journal of Service Research, 1(3), 236-249. http://dx.doi.org/10.1177/109467059913005

Bozkurt, İ. (2000). Bütünleşik Pazarlama İletişimi. MediaCat Yayınları, İstanbul.

BTK. (2012). Bilgi Teknolojileri ve İletişim Kurumu Üç Aylık Pazar Verileri Raporu. Retrieved from http://btk.gov.tr/kutuphane_ve_veribankasi/pazar_verileri/ucaylik12_3.pdf

Chan, Y. H. (2005). Basic statistics for doctors. Singapore Med J., 46(2), 54-62. Retrieved from http://www.sma.org.sg/smj/4602/4602bs1.pdf

Churchill, G. A. (1999). Marketing Research. Methodological Foundations $\left(7^{\text {th }}\right.$ ed.). The Dryden Press.

Çoban, S. (2005). Müşteri Sadakatının Kazanılmasında Veritabanlı Pazarlamanın Kullanımı. Erciyes $\begin{array}{llllll}\text { Universitesi S.B.E. Dergisi, 19, 295-307. } & \text { Retrieved from }\end{array}$ http://sbe.erciyes.edu.tr/dergi/sayi_19/sayi_19.htm

De Ruyter, K., \& Wetzels, M. (2000). Customer equity considerations in service recovery: a cross-industry perspective. International Journal of Service Industry Management, 11(1), 91-108. http://dx.doi.org/10.1108/09564230010310303

Doğan, G., \& Erdoğan, S. (2010). ISO 10002: Müşteri Memnuniyeti ve Müşteri Şikâyetleri Yönetimi. Borusan Lojistik Örneği, Lisans Proje Ödevi. İktisadi ve İdari Bilimler Fakültesi, Sakarya Üniversitesi.

Ertürk, K. Ö., \& Kıyak, C. M. (2011). Müşteri Memnuniyetini Artırma Aracı Olarak Halkla İlişkilere Maslow'un İhtiyaçlar Hiyerarşisi Pencersinden Bakmak. Iletiş̧im Kuram ve Araştırma Dergisi, 32, 127-150. Retrieved from http://www.iletisimdergisi.gazi.edu.tr/arsiv/32.pdf

Etzel, M. J., \& Silverman, B. I. (1981). A managerial perspective on directions for retail customer satisfaction research. Journal of Retailing, 57(3). 124-136. Retrieved from hattp://ehis.ebscohost.com/ehost/pdfviewer/pdfviewer?sid=5ed4a35a-c510-4a26-8343-9febb5359262\%4 0sessionmgr114\&vid=1\&hid=103

Gerson, R. (1997). Müssteri Tatmininde Süreklilik (Çev: Tülay Savaşer). İstanbul: Rota Yayınları.

Gilly, M. C., \& Hansen, R. W. (1985). Consumer Complaint Handling as a Strategic Marketing Tool. Journal of Consumer Marketing, 2(4), 5-16. http://dx.doi.org/10.1108/eb008139

Hair, Jr. J. F., Anderson, E. R., Tahtam, R. L., \& Black, C. W. (1998). Multivariate Data Analysis. Prentice Hall Inc.

Kang, J., Zhang, X., \& Zheng, Zhao-Hong. (2009). The relationship of customer complaints. satisfaction and loyalty: Evidence from China's mobile phone industry. China-USA Business Review, 8(12), 22-36. Retrieved

from 
http://ehis.ebscohost.com/ehost/pdfviewer/pdfviewer?sid=10153858-72b0-4f78-9342-31842622e238\%40s essionmgr110\&vid $=1 \&$ hid $=103$

Kızgın, Y. (2008). Genç gsm abonelerinin operatör seçimlerini etkileyen değişkenlerin konumlandırılması üzerine bir alan araştırması: Muğla Üniversitesi öğrencileri örneği. Balıkesir Üniversitesi Bandırma İ.I.B.F. Akademik Fener Dergisi, 10, 134-152.

Lewis, R. C. (1983). Consumers complain what happens when business responds. In Day, R. L. and Hunt. H. K. (Eds.), International Fare in Consumer Satisfaction and Complaining Behaviour. Department of Marketing, School of Business, Indiana University, Bloomington.

Li, D., Browne, G. J., \& Wether be, J. C. (2007). Online Consumers' Switching Behavior: A Buyer-Seller Relationship Perspective. Journal of Electronic Commerce in Organizations, 5(1), 30-42. http://dx.doi.org/10.4018/jeco.2007010102

Lumley, T., Diehr, P., Emerson, S., \& Chen, L. (2002). The Importance of the Normality Assumption in Large Public Health Data Sets. Annu. Rev. Public Health, 23, 151-169. http://dx.doi.org/10.1146/annurev.publhealth.23.100901.140546

Martin, B. W. (1997). Müssteri Hizmetlerinde Kalite (Çev. Ahmet Ünver). İstanbul: Rota Yayınları.

Mcdougall, H. G., \& Levesque, J. T. (1999). Waiting for Service: the Effectiveness of Recovery. International Journal of Contemporary Hospitality Management, 11(1), 6-15. http://dx.doi.org/10.1108/09596119910250346

Mjahed, S., \& Trike, A. (2009). Toward E-Knowledge Based Complaint Management. Retrieved from http://www.iajet.org/iajet_files/vol.1/no.1/Toward\%20E-Knowledge\%20Based\%20Complaint\%20Manage ment.pdf

Nakip, M. (2003). Pazarlama Araştırması Teknikler ve (SPSS Destekli) Uygulamalar.

Naylor, G. (2003). The Complaining Customer: A Service Provider's Best Friend. Journal of Consumer Satisfaction. Dissatisfaction and complaining Behaviour, 16, 241-248. Retrieved from http://lilt.ilstu.edu/staylor/csdcb/articles/Volume16/Naylor\%202003.pdf

Odabaşı, Y. (2000). Satış ve Pazarlamada Müşteri İlişkileri Yönetimi. Sistem Yayıncılık, İstanbul.

Odabaşı, Y. (2001). Pazarlama Planı Rehberi. Girişimciliği Geliştirme Merkezi, Ankara.

Oliver, R. L. (1997). Satisfaction: A Behavioural Perspective on the Consumer. Boston, MA: McGraw-Hill.

Özdamar, K. (1999). Paket Programlar İle İstatistiksel Veri Analizi. Kaan Kitabevi, Eskişehir.

Özdamar, K. (2003). Modern Bilimsel Araştırma Yöntemler. Kaan Kitabevi, Eskişehir.

Özdemir, E., \& Tokol, T. (2008). Kadın Tüketicilere Yönelik Pazarlama Stratejileri. Anadolu Üniversitesi Sosyal Bilimler Dergisi, 8(2), 57-80.

Parasuraman, A., \& Berry, L. (1997). Listening to the Customer: The Concept of Service Quality Information System. Sloan Management Review, 38(3), 65-76.

Sarıdaldi, E., \& Sevim, Ş. (2009). Müşteri Şikayet Yönetim Performansının Değerlendirilmesi. TCDD 3. Bölge Müdürlüğünde Bir Uygulama. Sosyal Bilimler Enstitüsü Dergisi, 12(22), 110-126.

Stat Trek. (2012). Sampling Distributions. Retrieved December 3. 2012 from http://stattrek.com/sampling/sampling-distribution.aspx

Statsoft. (2012). Are All Test Statistics Normally Distributed? Retrieved December 32012 from http://www.statsoft.com/textbook/elementary-statistics-concepts/

Stauss, B., \& Seidel, W. (1998). Beschwerdemanagement Fehler vermeiden Leistung verbessern Kunden binden $\left(2^{\text {nd }}\right.$ ed.). Hanser Verlag, Munchen/Wien.

Stauss, B. (2002). The dimensions of complaint satisfaction: process and outcome complaint satisfaction versus cold fact and warm act complaint satisfaction. Managing Service Quality, 12(3), 173-183. http://dx.doi.org/10.1108/09604520210429240

Şencan, H. (2002). Bilimsel Yazım. İstanbul Üniversitesi. İşletme Fak. Yayınları.

Whitelock, J., \& Jobber, D. (2004). An evaluation of external factors in the decision of UK industrial firms to enter a new non-domestic market: an exploratory study. European Journal of Marketing, 38(11), 1437-1454. http://dx.doi.org/10.1108/03090560410560182 